\title{
Challenges of Islamic Religious Education Due to The Implementation of 4.0 Industrial Era
}

\author{
Dede Rosyada $^{1}$, Andriyani ${ }^{2}$ \\ \{dede.rosyada@uinjkt.ac.id ${ }^{\mathbf{1}}$, andriyani@umj.ac.id² \\ ${ }^{1}$ Syarif Hidayatullah State Islamic University of Jakarta, Indonesia \\ ${ }^{2}$ Muhammadiyah University of Jakarta, Indonesia
}

\begin{abstract}
Islamic religious education is a compulsory subject for all students from all school levels in Indonesia, by the goals to promote the strength of belief, piety and noble morality, for being smart and competitive citizenship in the future. Religious competence isn't a main skill and expertise for commons students, because it isn't a profession except the students from religious education department that prepares the students for being religious teachers. Even so, it has a significance position to develop and maintain motivation, creativity and innovation, in facing the competition in the professional market. Moreover, nowadays, the world is facing a big problem with humanity as a result of industrial trend to optimise the position of Cyber Physical System (CPS), Internet of Thing (IoT), dan Internet of Service (IoS) in almost all production processes. So, Islamic religious education should extend the goals of learning process, not merely strengthening belief, piety and noble morality, but also openness, cross cultural relationship, and expanding the field of professional works, regional and global context. Along with it, Islamic religious education process also should upgrade the creativity and innovation competence for all the students through participative learning, problem solving, and project.
\end{abstract}

Keywords: Islamic religious education, creativity and innovation

\section{INTRODUCTION}

Islamic Education is a compulsory program at all levels of formal schools in Indonesia. Such a very strategic educational policy is underlined by Government Regulation No. 55 of 2007, as it is stated that religious education is an educational program to develop knowledge, attitudes, and personalities, as well as upgrading skills of students to practice religious teachings. This religious education program is implemented at least through subjects / lectures on all levels, and types of education [1]. At the same time, the Ministry of Religion Affairs as it is mandated ministry to organized the implementation religious education, is very serious in constructing planning, controlling learning processes and outcomes in the formal education pathway, both general and vocational education.

Religious education functions to form Indonesian people who believe and have faith in God Almighty and have good character and are able to maintain peace and harmony between religious and inter religious relations [1]. And Religious Education aims to develop the ability of students to understand, appreciate, and practice religious values that harmonize their 
mastery in science, technology and art [1]. This regulation is already very ideal, visionary and also very inclusive, namely that Religious Education, in the context of PAI, is expected to be able to bring students into children of faith, piety and be able to maintain harmony, peace and be able to live in mutual understanding of one another. If their souls have been formed like that, then they and the PAI are expected to make partnerships with anal-children Malaysia, Singapore, Vietnam and others from ten ASEAN countries. At the same time, PAI aims to become a professional spirit.

At the same time, the world is now entering the phase of the industrial revolution 4.0. Many explanations can be read about this industrial revolution 4.0, and why education people are always busy discussing sociological and pedagogical impacts that must be adjusted, so that those produced through education can enter the labor market well, do not experience maladjustment, so that their expertise or skills can be used for the advancement of his professionalism, and in a larger context can participate for the progress of the nation. The challenges of the industrial revolution 4.0 that have entered the era of digitalisation, automation, and do not require a lot of people, because industrial machines are driven by computers, many artificial intelligent models are displayed by robots, so the industrial needs of people are getting smaller, the cost of production is increasingly efficient, and manufactured industrial goods increasingly compete in the market to reach consumers.

This progress is a challenge for PAI teachers in all lines and levels of education to prepare students who will compete in the market, so that their presence in the labor market can be absorbed by industry, not because of labor-intensive policies from the government, but because industry does require skills and expertise they. Then, the industrial revolution 4.0 is also often referred to as a period of disruptive innovation, namely new innovations that were never unexpected and disturbing to established players, both in the manufacturing and service industries. For these two aspects, what should PAI teachers do? What can be done by PAI so that children of school and university alumni become creative and innovative people, so that they do not have problems with limiting employment, or encouraging them to be someone whose industry requires their expertise.

\section{INDUSTRIAL REVOLUTION 4.0}

Industrial revolution 4.0, a revolution in the industry which was originally in the 3rd generation industrial phase, only relying on the power of automation, computers and electrical energy, in phase 4.0 changed and developed into a Cyber Physical System (CPS), the Internet of Thing (IoT), and Internet of Service (IoS), and networks. All of these components are integrated into industrial processes both manufacturing, logistics and others [2]. Industrial revolution 4.0 is a shocking progress in the world, once the production process is controlled by a computer through CPS, production divisions are no longer needed, and once the cyber-based production process is over, marketing of goods and transactions are already using the internet and even by using applications in mobile phone. People presence in the production process is no longer needed, as well as transactions, once banking transactions are done online, the teller function is getting smaller, and there is a reduction in labor. Many functions of the human workforce are eroded by the presence of digital technology. Slamet Rosyadi firmly emphasized, that the fields experiencing breakthroughs thanks to new technological advances include (1) artificial intelligence robots, (2) nano technology, (3) biotechnology, and (4) quantum computer technology, ( 5) block chain (like bit coin), (6) internet-based technology, and (7) 3D printers [3]. 
The presence of intelligent artificial, digital technology and internet as a server that can store thousands or even millions data, is also supported by nano technology, so that over time the need for human labor will diminish. However, at the same time, Industrial Revolution 4.0 has opened up new opportunities with the presence of the internet as a server for big data, and open for everyone to access, without restrictions by power, because the data is presented so it can be accessed by many people as possible. People nowadays doing business through disruptive innovation, which is innovation that disrupts the key business. Reiterated by Slamet Rosyadi, that the era of disruption not only disrupted or damaged pre-existing markets but also encouraged the development of products or services that the market had not expected before, creating diverse consumers and impacting lower prices [3].

The term of industry 4.0 is a term that was introduced by Prof. Klaus Schwab [4] in his writing "the Fouth Industrial Revolution", and was officially introduced by the German government at the 2011 modern industry exhibition at the Hannover Fair, in order to launch the High Tech Strategy 2020 program [5]. Industrial Revolution 4.0 emphasizes the integration of cyber and industrial tools in an automated production process, connected to the internet, can read each other, so that the production process all runs mechanically and does not use much energy [6]. Thus, the production process is more efficient, and the price of goods is more competitive in the market. At this level, it is inevitable that there will be a reduction in human labor, because there is no need for industry anymore. This condition has been recognized by all nations in the world and there will be an explosion of unemployment everywhere, social crisis, and continues to spread to various sectors of economic, political, social and cultural life. The industrial era 4.0 is almost in all lines of production, marketing, shipping, and transactions, all involving computers and the internet. Therefore, this era is also commonly referred to as the digital era. Then, along with that, the use of computers as the main tool in the industry, and computers as data storage, non-confidence data is also stored on cyber devices, and everyone can access the data. This is the most modern new business, business people by calculating the frequency of access, and obtain the proportion of profits from the owner of the bandwidth. A new business term appears now, namely disruptive innovation, which is innovation that was never expected, and disturbing the main players in the business, and carried out by new players who may not be linear with their knowledge.

The industrial revolution is a new opportunity for everyone, unlike the previous generation who relied heavily on professionalism with a very narrow definition of linearity in education with work and profession. Nowadays in the digital era, the cyber era and big data can be accessed by everyone, and they can compete without having to register with formal institutions that want formality and linearity. Competencies that are really needed now are creativity and innovation, as well as communication and collaboration skills with each other, without being blocked by primordial differences. Thus, education must now train creativity, innovation, good communication and universal collaboration skills.

\section{CHALLENGES AND REORIENTATION OF ISLAMIC RELIGIOUS EDUCATION CURRICULUM}

Curriculum is not limited to documents containing Competency Standards, Basic Competencies, Competency Indicators and various planned topics of teaching materials, but the curriculum is all the experiences experienced by students, content of learning, methods of teaching and learning, assessment and even the whole experience students in the school in 
extra-curricular activities, student interaction with the teacher, administration and the entire school apparatus, is the curriculum [7], because everything is the part of the process of changing students' attitudes and personalities. To facing the industrial era 4.0, the definition of curriculum must be broadened in this sense.

Islamic Religious Education (PAI) obtains a mandate from God as the process of preparing the present and future generations as the best generation on earth (Ali Imran 110). In this verse it is emphasized that to be the best people must do three things, always ordering to do good deeds, always preventing Muslims from doing bad deeds, and always maintaining and strengthening the faith in God. As an effort to realize this ideal, the Indonesian government has adopted a strategic policy on religious education, which is affirmed in Government Regulation no. 55 year 2007, article 2 paragraph 1 and 2, which reads: Religious education functions to form Indonesian people who believe in and fear God The Almighty and noble character and able to maintain peace and harmony interfaith religious relations. Religious education aims to develop the ability of students in understanding, living, and practicing religious values that harmonize their mastery in science, technology and art [8]. Based on this regulation, the functions of Islamic Religious Education are:

3.1. Forming students to become believers, religious beliefs are the basis of all professional, social and personal actions, religious beliefs are the control of professional, social and personal actions, and religious beliefs are the destination of all of the human activities.

3.2. Forming a pious human being, that is carrying out all acts of worships, and also valuing of worship for all professional and social deeds, avoiding everything that is prohibited by religion, and guarding himself for not committing wrong to anyone and to anything.

3.3. Forming students to become noble morality, in all contexts of their professional, social and personal lives.

3.4. Forming students to be able to maintain peace and harmony, respect to the different ethnic, cultural, and religion differences, and be ready to collaborate on diversity.

Then, the aims of Islamic Religious Education are:

3.1. Teaching the students to understand, live and practice the teachings of the religious doctrines

3.2. Teaching the students to be able to harmonize their mastery of Islamic Religious Education with the mastery and implementation of science and technology. So, main goal of Islamic Religious Education is integrating their religious belief systems in the professional and social lives.

The industrial era 4.0 is characterised by two very severe situations:

3.1. Industry will rely more on computers and robots, so that human labor will be radically reduced. Thus, the employment of school and university alumni will face great difficulties in finding professional works.

3.2. However, the cyber era also brings great benefits if it can be optimized for all its opportunities. Therefore, this era is often referred to as the era of disruptive innovation. This innovation is open to anyone, because everyone becomes his own boss, for his own ideas and dreams.

The demand for success in the industrial era 4.0 are as follows:

3.1. Must be a creative citizens, so they can become very independent

3.2. Must be an innovative people, in order to succeed in his own creativity-based business.

3.3. Must be an inclusive citizen, so they can collaborate across ethnic, cultural and different religious followers, so that their world view is not narrow, but at least ASEAN as a single market can be optimized. 
Does the Islamic religious education reach the areas of creativity, innovation and inclusiveness? Theoretically, creativity and innovation have no specific subject matter. Therefore, these two skills are entrusted to the pedagogical process, for this reason, Indonesia shifted from the behaviourism paradigm of teaching to constructivism of learning process, in an effort to maximize educational outcomes in order to produce intelligent, creative and innovative citizens. While inclusiveness is the subject of discussion that has long existed in teaching materials for school students, both middle and high school, maybe even since elementary education level.

Based on this description, the reorientation of the Islamic Religious Education curriculum requires that the output of Islamic Education in schools, which should be developed, guided and taught by alumni teachers majoring in Islamic Education study programs are:

3.1. Having great competence and commitment in the religious doctrine of belief

3.2. Having enough competence of obedience and piety

3.3. Having great competence of noble morality

3.4. Having competence and commitment to live tolerance amongst diversity

3.5. Having the competence to integrate the spirit of religious doctrines into professional, social and personal behaviour

3.6. Having openness behaviour and outlook, so that they can work together across cultures, ethnicities and religions

3.7. Become creative people, so they can be more independent in development. Life through partnership in business with all ASEAN people nations.

3.8. Become innovative people, so as to produce something that people in the world need the results of their work.

Islamic religious education Nowadays is challenged by industrial revolution 4.0 with disruptive innovation, which is innovation based on creativity, and does not demand linearity. Students who are studying in schools / Madrasah, and even students who are studying in tertiary institutions, will eventually become professionals in their work environment, whether as entrepreneurs, employees, or providing services to the community. The development of business since industry 4.0 , is very interesting because everyone can become a business person with his creativity, because the opportunities are wide opened for everyone. Based on such reason, Islamic religious education should be reoriented, to open students' mind, for extending cross religion partnership. And the chaining should be done comprehensively not only content of learning but also learning methodology, and learning orientation.

Frequently the word creativity is attached to works of art, music performances and painting exhibitions, whereas creative words are also related to business, manufacturing, health and medical services, education, and various other activities. Thus, creativity exists in all parts of life. Creativity is, the ability to give birth to a new innovation, original, never thought before, quality and as expected, can be used for a job which is useful for achieving goals. In creativity, there is something new, original and useful for an institution in achieving its goals [9]. Then there are those who interpret that creativity is a serious desire to explore, do imagination and rethink something based on the knowledge, experience, and feelings they have, to produce an original product and effective or efficient, as needed [10].

There are several characteristics of creativity, or in other words someone who is creative will have these characteristics. Based on the results of his research which was very old in 1973, JP Guilford concluded that a creative person would have the following characteristics1 [11]:

3.1. Flexibility, which has the ability to get out of tradition and habits, to get new ideas, differences and unusual results. 
3.2. Fluency; Having the ability to think a lot of ideas, and many alternative problem solving.

3.3. Elaboration; Having the ability to work out the details of every idea and solution

3.4. Tolerance and ambiguity; Having the ability to reconcile ideas that conflict with one another, without creating new tensions.

3.5. Originality: Having the ability to give birth to ideas, thoughts, models, which are completely new, different from the others, and able to give birth to something that is truly outside of the existing.

3.6. Sensitivity: Having sensitivity to problems that arise in the environment.

3.7. Curiosity: Having an open attitude towards new inputs, new information, and having a strong desire to use the various information that it has to solve the problems it faces.

3.8. Independence; Having the ability to think and think about problems with their own abilities.

3.9. Action; Having the ability to turn his ideas into reality, with enthusiasm and energy.

3.10. Commitment; Having a high commitment and concern to resolve the problem with new ideas and ways.

Based on the definitions and explanations of the characteristics above, then the attitudes and creative actions can be done by anyone [12], as long as they have a strong desire to do it, and have a commitment to continuously maintain consistency to always be involved in solving problems in the company, in government offices, in schools and universities, and even in social settings. Someone who has the ability to be creative will always think of existing problems, based on existing knowledge, and give birth to ideas, ideas, and maybe even new models that others have never found. Thus, creativity can be developed. And the only development is through the education process. However, so far, there are no "Development of creativity and innovation" subjects or courses, because they are not one discipline, but one subject in certain subjects or subjects. Therefore, developing attitudes and creative behavior can only be developed through the learning process, which inserts creative themes in relevant subjects or subjects. Nevertheless, these attitudes and behaviors must be evaluated in the final evaluation of the relevant subject or subject. Indicators about create, invent, discover, imagine, suppose, must be detected in the development of their affection for students through evaluations [13]. Then, in addition to inserting content in relevant subjects or subjects, the creativity of students and students can be developed through learning that trains them to become creative people. Creativity is not born, but developed, creativity is not a factor of heredity, but the result of coaching.

\section{PEDAGOGY REFORM IDEAS FOR THE DEVELOPMENT OF CREATIVITY}

The need for variating and pedagogical dynamiting between high school and university students is different. Need to find a great mastery of the learning materials for the students of university is more then the students of high and secondary school. The focus of this pedagogical reform is dedicated to high school students, but it does not rule out the possibility, it is also needed for students in the early undergraduate programs. This pedagogical reform was put forward by a team of writers from an educational, research and development institute called the Innovation Unit based in London UK. This book was written as an idea facing the millennial era, which at the same time they are in the digital age and in the era of disruptive innovation. They have a very different character from the new generation of the 20th century. 
The educational process in the past, was very bound by the classroom, limited by four areas of the wall, set the time of learning hours as well as the schedule of lessons, the frequency of learning in each subject. Students are bound to the recommended textbooks in the curriculum, and the teachers are also bound by some finite learning programs, and students must learn whatever the teachers are coming in or not, and even they are mastering materials or not. New ideas are now being developed that may be relevant to the needs of the 21 st century, and relevant to the changing of educational policies due to the coming of industry 4.0 era, which require extraordinary creative abilities. The pedagogical model they learn must be different when learning resources are very diverse, easily accessible, inexpensive and allow to learn teaching materials beyond the limited plans that have been designed in the documented curriculum. These ideas are as follows [14]:

4.1. Open up lesson (open learning). The learning process of students are regulated and controlled by the teachers. It is common in many classes in many schools. The teacher conveys the topic, subject matter, sometimes they explain the material then give a test. Even though the offerings are not necessarily in accordance with what students need, so their motivation decreases, students become unenthusiastic about learning, time is wasted, just because teachers do not understand the needs of their students to learn. It is better to let the students and / or students set themselves, what they want to learn in order to achieve the goals that have been formulated by the teacher, and the teacher is enough to provide support and assistance more closely, so they feel they receive serious attention from their teachers. Students must be respected for their freedom to learn, but are burdened with the responsibility of achieving standard competencies (learning objectives) that have been set in the learning program. Instead of the teachers only accompanies them to learn, and the interaction between students and teachers can be closer and more meaningful.

4.2. Think outside the Classroom. Traditional classrooms are usually neatly arranged, students sit on benches or chair with small tables facing the teacher, and the teacher has a role to convey the lesson for them. Now the paradigm has changed, economic development, science and technology and even world civilisation is moving very fast. While students are circled by easily accessible sources of science and technology. Thus, it is very likely that students entering the classroom already carry a lot of information that they have an access to in cyberspace, and even the class becomes an arena to pursue scientific and technological information for them to learn, not as an arena for exposing scientific and technological information. Thus, it is not possible to pretend and even design a class for presentation space, but leave the class as an arena for students to find their own knowledge according to what they need to learn. The teacher only facilitates class library, modules, textbooks, and supporting books, and most importantly internet access, and provides several PCs for students who do not carry a laptop or accessible tools to the information.

4.3. Get Personal. Usually in the world of education there are classifications of students with special needs, and they are specially served by teachers. Now all children with special needs, also need special services. All of the children can not be combined in the same class, and at the same time, in the same subject learn the same material from one teacher, because it is possible that what the teacher presented is already well understood by some students, and still needed by others, so, on that day, some certain students become losers, because they don't get what they need. And it won't be enough time if the teacher has to present everything that the students want to know, because each of them has different needs. Therefore, services for students in the classroom must be more personal, leaving 
the class as an arena for students to find their own knowledge according to what they need for them to learn. The teacher only facilitates class library, modules, textbooks, and supporting books, and most importantly internet access, and provides several PCs for students who do not carry a laptop or.

4.4. Tap in to Students' digital expertise. Students should be accustomed to using the internet as a learning resource, student interaction with teachers or lecturers can use digital communication media, teachers can give their assignments via the internet, and students / students deliver their assignments also through the same media. They can share information with their friends through social media, Facebook, WA, Twitter, Instagram or others. And many schools allow their students to use Android to access teaching materials as a substitution for laptops that may cost more.

4.5. Get Real With The Project. Now high school students are familiarized with research assignments in the mini research scheme. The activity is usually referred to as a project. Projects in the academic tradition are an excellent policy, because students are trained to conduct studies and analysis of a comprehensive, multi-disciplinary focus and go beyond the scientific boundaries of each discipline. This kind of project, besides being able to increase students' scientific maturity, they are also trained to work in teamwork, practice managing time to work, and at the final stage present their work in a school forum with a variety of listeners and observers. These skills and competencies will be needed to be successful in their career and profession after they leave school.

4.6. Expect students to be Teachers. Giving trust to students to act as teachers to their peers in the learning process in the classroom. The task of the teacher is to provide assistance, guidance and assistance and training to students including the task of transforming knowledge that is very broad, as well as training skills that are appropriate to the needs of their profession. However, there is also a small part or maybe even a large portion among students that already have very broad and varied knowledge and skills with their own efforts to access various learning, training or other sources. In this context, the teacher can portray students to become teachers in their peer group or peer tutors, especially to their classmates, and maybe even become teachers for their own teachers. This method will greatly enable students to shape and develop their own education, without being limited to the curriculum prepared by the school.

4.7. Help Teachers to be Students, which is helping or reminding teachers to become students, or to become learners and continue to learn without stopping even though they have become a teacher. The 21 st century challenges young people to be good learners, they are required to always be learners and can learn from the mistakes they have made. They must become independent learners, not because of the teacher's orders or school work, but to learn on their own, and the learning process is theirs, not the school's or teacher's. They must be familiar with a flexible learning process, use different strategies, and keep abreast of the changing world very quickly. If students are able to achieve changes quickly and independently, the teacher must be able to balance these changes. Only one of the best ways for teachers is to be a continuous learner, in more extreme terms, the teacher must be prepared to be an occasional student.

4.8. Measure What Matters (Measurement of learning outcomes). Measurements, what we want to measure for sure are the materials that have been taught, and how to do measurements, will greatly affect the way of teaching. Therefore, it is reasonable to ask whether the measurement was carried out to ensure that the students had become what they wanted. In fact, developments outside the school are so advanced and students are individually demanded to be able to follow progress outside of school in order to enter the 
world of profession properly. Thus, the measurement and assessment of learning outcomes becomes insignificant, because the development is very dynamic and the curriculum has not been able to keep up with these changes. Nevertheless, this paper is not denying assessment, but is illustrating that education is very dynamic, and students can be more advanced than the curriculum and can also be more advanced than the teacher himself. Because the assessment and measurement must be done at all times, continuously and not dependent on class or school curriculum, but instead, they do it themselves in the learning process.

4.9. Works with Families not Just Children. Working with families not only with children. It has been widely recognized that parental involvement in children's education has a very strong positive correlation with student achievement. Some schools collaborate with people in various ways so that their children are the best they can be. And even some schools collaborate with families for a greater interest, not just the achievement of their children's academic achievement, but instead discussing to design curricula that can meet the external challenges of the school for their profession later.

4.10. Power to the Student, is sharing power for students. Students' voices, is the way they can say whatever they want to say as a form of understanding of the issue or situation experienced or faced. In fact, students may be given the opportunity to take control of the school, so that they continue to make improvements in increasing their contribution to students studying at the school.

These ten ways of learning are really the result of reflection of education activists from the Innovation unit in London, by trying to see the practices carried out in several schools that carry humanistic education in the paradigm of democratic learning. All of the above ideas still require the study of technological formulations and instruments, as well as testing of these technologies and instruments in implementation at school or university. Indeed, it is very rational, like what for a test, if it will only narrow the knowledge of students, because students can learn from a variety of sources they have, laptop, Ipad, android or others who can access on the internet, which presents very much information in science and technology that many students need to become professionals.

Similarly, students who can be teachers or peer tutors in their class, and vice versa teachers who must be students. Thus, the teacher can assign them to share their fellow peer groups in the classroom, or outside the classroom, or maybe even become a teacher for their own teacher. Relationships in the classroom are no longer teachers and students, but senior learners with junior learners, who can share with one another. All of these formulations are interesting reformist ideas to try to be instrumented and validated empirically, so that they can really be utilized to produce new pedagogical models and be able to produce competitive, and intelligent students. This learning model gives students the opportunity to study teaching material far from what the teacher is targeting, and may even reach relevant but not programmed topics. And the most important that all these ways of learning can be used on teaching Islamic religious education, to accelerate and optimise students' understanding to all learning materials and to reach the goals of learning.

\section{CONCLUSION}

The industrial era 4.0 is a big challenge for educators, especially for Islamic religious education, because all the Islamic religious teachers have to teach religious education, at the same time they are also requested to promote creativity and innovation, disruptive innovation 
through pedagogical approach by giving a wide opportunity for all students to learn. The Islamic religious teachers should give some projects for the students to observe the reality amongst social life, relevance to the substance of learning materials in classroom. And then, the teachers are also expected to extend the academic activities for all students by assigning them to read some books, summarising, and presenting it in the classroom, to be discussed together in the learning hours.

Beside of all those noble works of the teachers of Islamic religious education, they are also expected to enrich learning material by inserting some titles concerning inclusiveness, pluralism, and cross cultural relationship and collaboration, because the students will enter a border less market to enhance productivity of the nation through its people, by extending social communication and partnership. It is hopefully requested for the teachers to encourage their students for the international human resource. So, they should think globally, and work locally to develop the economic life of the country. Islamic religious education isn't a subject to develop skill and expertise, but mostly as the spirit power for the students to grow up as a smart and competitive citizen in the future.

\section{REFERENCES}

[1] Government Regulation No. 55 Year 2007, tentang Pendidikan Agama dan Pendidikan Keagamaan,

[2] Prasetyo, Hoedi, Wahyudi Sutopo (2018), Industri 4.0: Telaah Klasifikasi Aspek dan Arah Perkem-bangan Riset, Jurnal Teknik Industri, vol. 13, no. 1, Undip, Semarang. p. 19.

[3] Rosyadi, Slamet, (2018), Revolusi Industri 4.0 : Peluang dan Tantangan Bagi Alumni Universitas Terbuka, Makalah, Fakultas Ilmu Sosial dan Ilmu Politik Universitas Jenderal Sudirman.

[4] Lee, MinHwa, JinHyo Joseph Yun, Andreas Pyka, DongKyu Won, Fumio Kodama, Giovanni Schiuma, HangSik Park, Jeonghwan Jeon, KyungBae Park, KwangHo Jung,Min-Ren Yan, SamYoul Lee, and Xiaofei Zhao, (2018) How to Respond to the Fourth Industrial Revolution,or the Second Information Technology Revolution? Dynamic New Combinations between Technology, Market, and Society through Open Innovation, Journal of open Innovation, Technology, Market and Complexity, doi:10.3390/joitmc4030021.

[5] Prasetyo, Hoedi, Wahyudi Sutopo (2018), Industri 4.0: Telaah Klasifikasi Aspek dan Arah Perkem-bangan Riset, Jurnal Teknik Industri, vol. 13, no. 1, Undip, Semarang.

[6] Muhammad Yahya, Muhammad, (2018), Era Industri 4.0: Tantangan dan Peluang Perkembangan Pendidikan Kejuruan Indonesia, Professor Inaugural Speech, UNM, Makassar.

[7] Wen Su, Shao (2012), The Various Concepts of Curriculum and the Factors Involved in Curricula-making, Journal of Language Teaching and Research

[8] Government Regulation No. 55 year 2007, article no. 1 paragraph no. 1 and 2.

[9] Samašonok, Kristina, Birutė Leškienè-Hussey (2015), Creativity Development: Theoretical and Practical Aspects, Journal of Creativity and Business Innovation, Vol. 1.

[10] Thi Bich Tran, Lieu, Nhat Thi Ho, and Robert J. Hurle (2016), Teaching for Creativity Development: Lessons Learned from a Preliminary Study of Vietnamese and International Upper (High) Secondary School Teachers'Perceptions and Lesson Plans, Scientific Research Publishing, Creative Education. 
[11] Guilford, J.P., (1973), Characteristics of Creativity, Department for Exceptional Children, Springfield, Illinois.

[12] Cropley, A. J. (2011). Definitions of creativity. In M. A. Runco \& S. R. Pritzker (Eds.), Encyclopedia of creativity (pp. 511-524). San Diego, CA: Academic Press.

[13] Thi Bich Tran, Lieu, Nhat Thi Ho, and Robert J. Hurle (2016), Teaching for Creativity Development: Lessons Learned from a Preliminary Study of Vietnamese and International Upper (High) Secondary School Teachers' Perceptions and Lesson Plans, Scientific Research Publishing, Creative Education.

[14] Hampson, M. Martha, Patton, A. \& Shanks, L. (2013), 10 Ideas for 21st Century Education, Innovation Unit, London, UK. 